Compans RW, Harter DH, Choppin PW (1967) Studies on pneumonia virus of mice (PVM) in cell culture. II. Structure and morphogenesis of the virus particle. J Exp Med 126:267276

Curnen EC, Horsfall FL Jr (1947) Properties of pneumonia virus of mice (PVM) in relation to its state. J Exp Med 85:39_ 53

Harter DH, Chopping PW (1967) Studies on pneumonia virus of mice (PVM) in cell culture. I. Replication in baby hamster kidney cells and properties of the virus. J Exp Med 126:251266

Horsfall FL, Hahn RG (1940) A latent virus in normal mice capable of producing pneumonia in its natural host. J Exp Med 71:391-408

Hou S, Doherty PC, Zijlstra M, Jaenisch R, Katz JM (1992) Delayed clearance of Sendai virus in mice lacking class I MHC-restricted CD8 ${ }^{+}$T cells. J Immunol 149:1319-1325

Joncas J, Berthiaume L, Pavilanis V (1969) The structure of the respiratory syncytial virus. Virology 38:493-496

Mohanty SB, Ingling AL, Lillie MG (1975) Experimentally induced respiratory syncytial viral infection in calves. Am J Vet Res 36:417-419

Parker JC, Richter CB (1982) Viral diseases of the respiratory system. In: Foster HL, Small JD, Fox JG (eds) The mouse in biomedical research, vol 2, diseases. Academic, New York, chap 8

Parker JC, Tennant RW, Ward TG (1966) Prevalence of viruses in mouse colonies. Natl Cancer Inst Monogr 20:2536

Prince GA, Porter DD (1976) The pathogenesis of respiratory syncytial virus infection in infant ferrets. Am J Pathol 82:339-352

Prince GA, Jenson AB, Horswood RL, Camargo E, Chanock RM (1978) The pathogenesis of respiratory syncytial virus infection in cotton rats. Am J Pathol 93:771-791

Tennant RW, Parker JC, Ward TG (1965) Virus studies with germ-free mice. II. Comparative responses of germ-free mice to virus infection. JNCI 34:381-387

Tennant RW, Parker JC, Ward TG (1966) Respiratory virus infections of mice. Natl Cancer Inst Monogr 20:93-104

Vogtsberger LM, Stromberg PC, Rice JM (1982) Histological and serological response of $\mathrm{B}_{6} \mathrm{C}_{3} \mathrm{~F}_{1}$ mice and $\mathrm{F} 344$ rats to experimental pneumonia virus of mice infection. Lab Anim Sci 32:419 (abstract)

Weir EC, Brownstein DG, Smith AL, Johnson EA (1988) Respiratory disease and wasting in athymic mice infected with pneumonia virus of mice. Lab Anim Sci 38:133137

\title{
Rat Coronavirus Infection, Lung, Rat
}

\author{
David G. Brownstein
}

Synonym. Parker's rat coronavirus, rat submaxillary gland virus, sialodacryoadenitis virus

\section{Gross Appearance}

Naturally infected adult rats rarely have grossly observable lung changes. Elsewhere macroscopic lesions are absent or confined to salivary glands and periglandular tissue. Ocular changes may also occur as a consequence of keratitis sicca. Axenic rats experimentally infected with Parker's rat coronavirus (PRC) develop gross lesions in the lung on postinnoculation days 6 and 7 , which consist of randomly dispersed red-brown to gray foci less than $1 \mathrm{~mm}$ in diameter (Bhatt and Jacoby 1977). Although PRC may cause fatal pneumonia in a high percentage of newborn and day-old rats, gross pulmonary lesions have not been described (Parker et al. 1970). Outbred young adult SPF Wistar rats experimentally infected with sialodacryoadenitis virus (SDAV) develop mild randomly dispersed red foci 5-7 days after intranasal inoculation (Wojcinski and Percy 1986).

\section{Microscopic Features}

Lung changes in young adult rats are mild and short-lived irrespective of the infecting strain. Nonsialotropic strains such as PRC produce hyperplasia of bronchusassociated lymphoid tissue (Fig. 356), perivenular lymphoid infiltrates (Fig. 357), and patchy interstitial pneumonia (Fig. 358; Bhatt and Jacoby 1977). Sialotropic strains such as SDAV produce more severe acute inflammatory changes in bronchioles and lung parenchyma (Wojcinski and Percy 1986). Random patches of bronchiolar epithelium undergo necrosis in conjunction with infiltration and exudation by neutrophils. Acute inflammation may extend from terminal bronchioles into adjacent alveoli. Affected alveolar septa are edematous, infiltrated by leukocytes, and alveolar spaces contain desquamated pneumocytes, macrophages, 


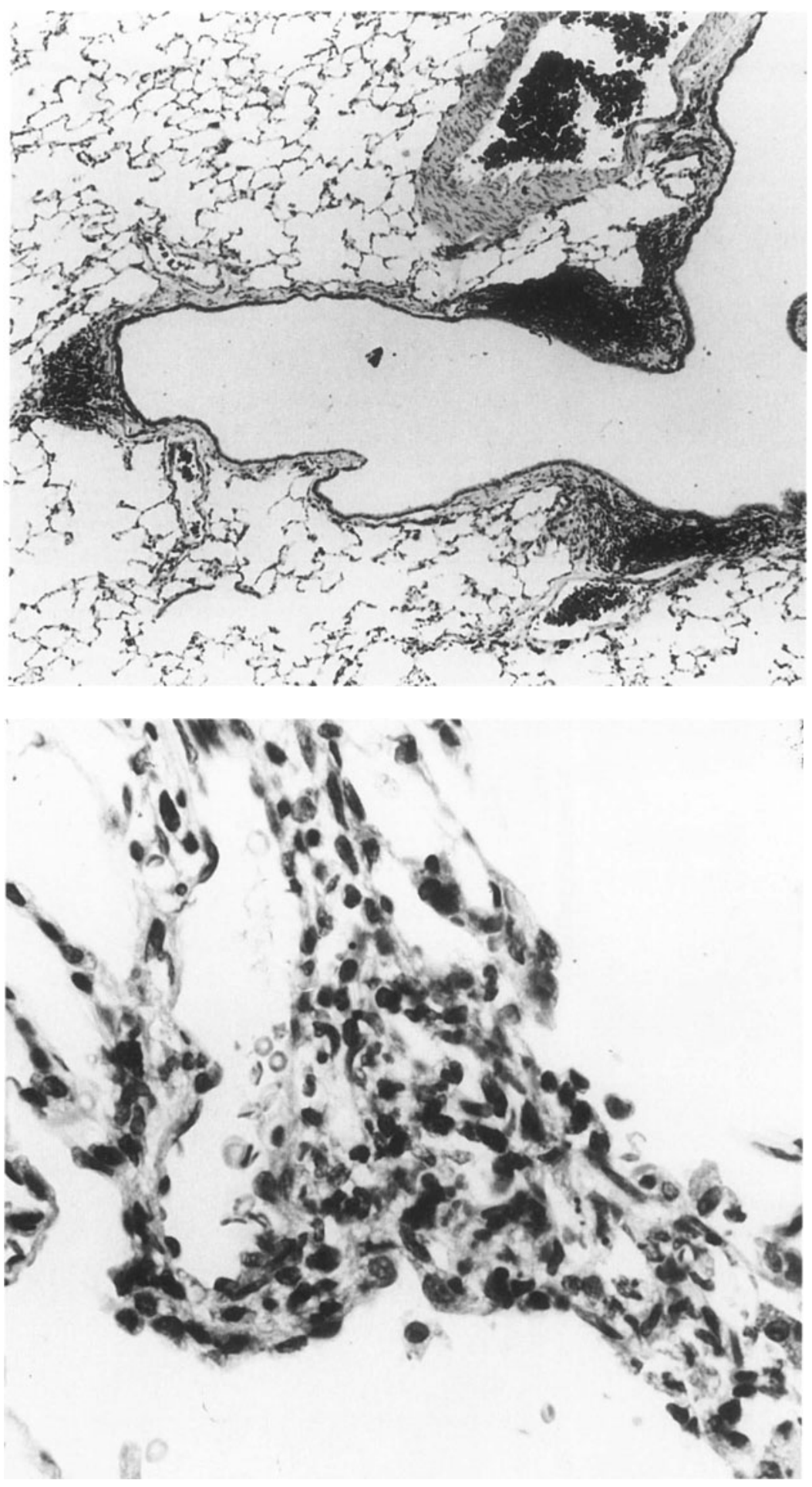

Fig. 356. (above) Rat coronavirus infection, lung. Bronchiole with mildly hyperplastic lymphoid nodules following experi-

Fig. 357. (below) Rat coronavirus infection, lung. Perivenular mental infection. H\&E, $\times 58$

lymphoid cells in an experimentally infected rat. H\&E, $\times 536$ 
Fig. 358. Interstital pneumonia following experimental infection with rat coronavirus.Alveoli contain foamy macrophages and lymphoid cells. Septa are inflitrated with mononuclear cells. $\mathrm{H} \& \mathrm{E}, \times 536$

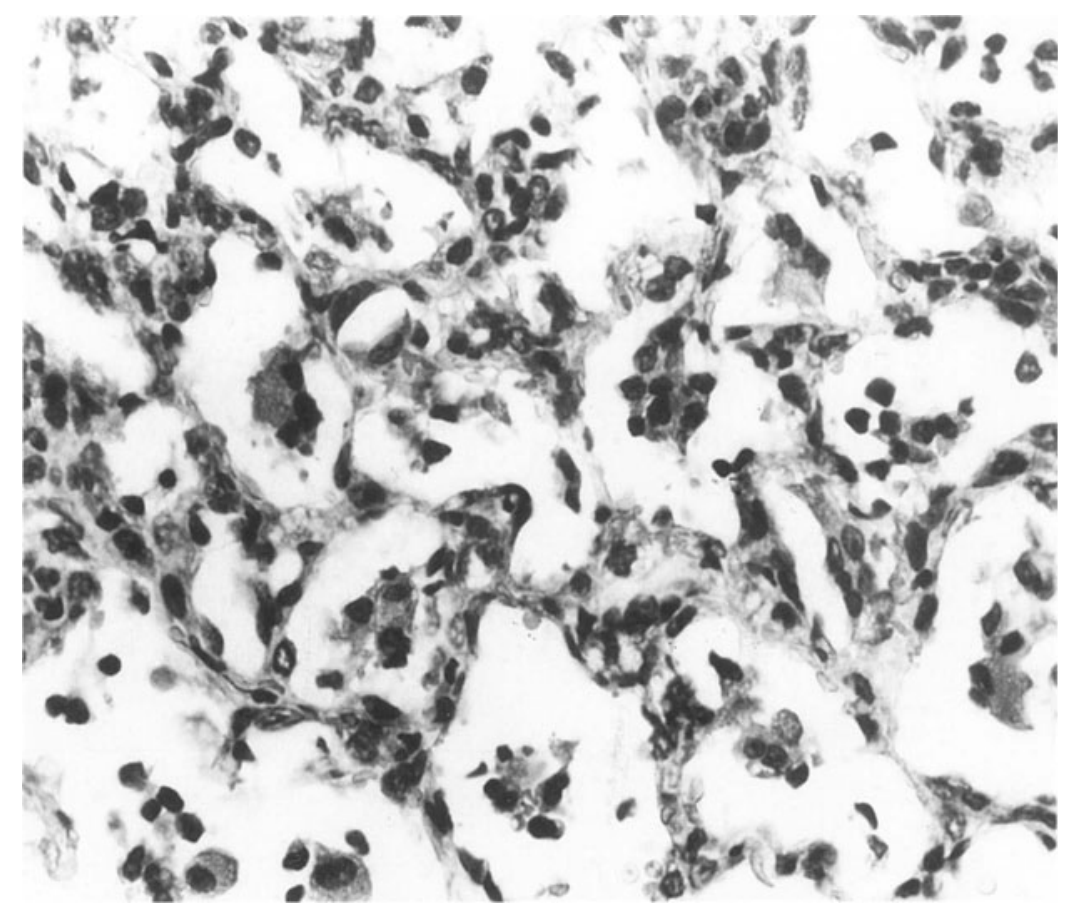

and neutrophils. The reparative phase is characterized by hyperplasia of bronchiolar epithelium and pneumocytes, infiltration by lymphoid cells, hyperplasia of bronchus-associated lymphoid tissue, and perivenular lymphoid infiltrates (Wojcinski and Percy 1986).

Transient rhinotracheitis also occurs which is more severe with SDAV than with PRC. In the former there is epithelial erosion and necrosis of perilaryngeal glands and ducts (Wojcinski and Percy 1986). In the latter there may be segmental erosion of epithelium covering nasal turbinates. In both cases lamina propria of the nasal cavity is edematous and infiltrated by lymphocytes and neutrophils. Some nasal respiratory surfaces are covered with exudate consisting of mucus, neutrophils, desquamated epithelium, and detritus.

Lesions of salivary glands are common with SDAV and uncommon or mild with PRC. With SDAV severe inflammatory changes occur in mixed or serous salivary glands, exorbital glands, and harderian glands. Mild parotitis and submaxillary sialoadenitis may occur with PRC. Description of these changes is beyond the scope of this chapter. The reader is referred to several excellent studies of sequential changes in these tissues (Innes and Stanton 1961; Jacoby et al. 1975, 1979; Bhatt and Jacoby 1977).

\section{Ultrastructure}

Infected epithelial cells have focally dilated cisternae of endoplasmic reticulum and cytoplasmic vacuoles which contain spherical dense cores $60-70 \mathrm{~nm}$ in diameter (Parker et al. 1970; Jonas et al. 1969). The characteristic corona, seen in negatively stained preparations, is not seen by transmission ultramicroscopy.

\section{Differential Diagnosis}

Respiratory tract lesions must be differentiated from those caused by Sendai virus, pneumonia virus, Mycoplasma pulmonis, and pathogenic bacteria. Identification of the infecting agent is necessary for definitive diagnosis.

\section{Biological Features}

Etiology. Rat coronaviruses are typical members of the Coronaviridae; pleomorphic, enveloped RNA viruses with plump, pedunculated surface projections (corona) measure $76-98 \mathrm{~nm}$ in diameter in negatively stained preparations $12-25 \mathrm{~nm}$ surface projections (Parker et al. 1970). Viruses are formed in cytoplasmic vesicles and cisternae of 
endoplasmic reticulum. The viruses are closely related to mouse hepatitis virus (Bhatt and Jacoby 1977).

Natural History. Rat coronaviruses cause acute limited infections except in immunologically disabled individuals such as athymic rats. They are highly contagious and are transmitted by aerosol, by direct contact, and transiently by fomites. There are two patterns of infection. Enzootic infections occur primarily in breeding colonies, where sucklings are passively immune, adults are actively immune, and weanlings are a continuous source of susceptible individuals due to waning passive immunity. It is therefore weanlings that generally exhibit clinical signs. Epizootics occur in nonimmune colonies, where morbidity is most likely to occur in young or aged animals. With SDAV the signs are usually transient and consist of intermandibular and cervical edema, swelling of submaxillary glands, sneezing, nasal and ocular discharges which are often red-tinged due to a high content of porphyrin, photophobia, and keratoconjunctivitis and its sequelae. Some complications of keratoconjunctivitis, such as glaucoma and phthisis, cause permanent disfigurement (Jacoby et al. 1979). Subclinical infections are the rule for PRC and are common for SDAV. Extensive host range studies have not been carried out but SDAV can be used to infect mice by the respiratory route (Bhatt et al. 1977).

Pathogenesis. Rat coronaviruses are epitheliotropic and replicate at all levels of the respiratory tract during the 1st week of infection. The highest respiratory titers are reached in the nasal cavity and trachea. SDAV but not PRC replicates extensively in certain exocrine tissues of the head. Neutralizing antibodies are detectable on day 6 or 7. Complement-fixing antibodies appear later and cross react with mouse hepatitis viral antigens (Bhatt and Jacoby 1977; Parker et al. 1970; Jacoby et al. 1979).

Frequency. Coronavirus infections are common in institutional rat colonies and in some commercial colonies. Different strains of rat coronavirus cannot be distinguished serologically.

\section{Comparison with Other Species}

Coronaviruses are ubiquitous in humans, animals, and birds (Bohl 1981). They cause enteritis in swine, cattle, dogs, mice, turkeys, and humans; encephalomyelitis in swine and mice; sialodacryoadenitis in rats; and respiratory infections in chickens, rats, and humans. Avian infectious bronchitis virus infects the trachea and lungs of chickens, causing respiratory distress, especially in young chicks. The virus also replicates in kidneys, bursae, and oviducts, producing inflammatory disease at these sites. Human respiratory coronaviruses are apparently restricted to the upper respiratory tract, causing rhinotracheitis and pharyngitis.

\section{References}

Bhatt PN, Jacoby RO (1977) Experimental infection of adult axenic rats with Parker's rat coronavirus. Arch Virol 54:345352

Bhatt PN, Percy DH, Jonas AM (1972) Characterization of the virus of sialodacryoadenitis of rats: a member of the coronavirus group. J Infect Dis 126:123-130

Bhatt PN, Jacoby RO, Jonas AM (1977) Respiratory infection in mice with sialodacryoadenitis virus, a coronavirus of rats. Infect Immun 18:823-130

Bohl EH (1981) Coronavirus: diagnosis of infections. In: Kurstak E, Kurstak C (eds) Comparative diagnosis of viral diseases, vol 4. Academic, New York, chap 7

Innes JRM, Stanton MF (1961) Acute diseases of the submaxillary and harderian glands (sialodacryoadenitis) of rats with cytomegaly and no inclusion bodies. Am J Pathol 38:455-468

Jacoby RO, Bhatt PN, Jonas AM (1975) Pathogenesis of sialodacryoadenitis in gnotobiotic rats. Vet Pathol 12:196209

Jacoby RO, Bhatt PN, Jonas AM (1979) Viral diseases. In: Baker HJ, Lindsey JR, Weisbroth SH (eds) The laboratory rat, vol 1. Academic, New York, chap 13

Jonas AM, Craft J, Black L, Bhatt PN, Hilding D (1969) Sialodacryoadenitis in the rat. A light and electron microscopic study. Arch Pathol 88:613-622

Parker JC, Cross SS, Rowe WP (1970) Rat coronavirus (RCV): a prevalent, naturally occurring pneumotropic virus of rats. Arch Gesamte Virusforsch 31:293-302

Wojcinski ZW, Percy DH (1986) Sialodacryoadenitis virusassociated lesions in the lower respiratory tract of rats. Vet Pathol 23:278-286 